\title{
The Effect of the Use of Flipbook Culture Story Media on Reading Literations of Elementary School Students
}

\author{
Liya Atika Anggrasari ${ }^{1 *}$, Dian Permatasari Kusuma Dayu ${ }^{2}$, Thitania Ambar \\ Widihantari ${ }^{3}$, Niken Dwi Setyaningsih ${ }^{4}$
}

\author{
1,2,3 Universitas PGRI Madiun, East Java, Indonesia \\ ${ }^{4}$ SDN Serdang 7 Jakarta Pusat, Jakarta, Indonesia \\ *Corresponding author. Email: liyaatika90@gmail.com
}

\begin{abstract}
This study aims to determine the effect of using the flipbook culture story media on the reading literacy of elementary school students. This research is quantitative research with a true experimental design that is a post-test only design. The population in this study were all grade 5 students of an elementary school in the Taman Madiun. Data collection techniques using observation, interviews, and tests. The results of data analysis showed that there was a difference in the post-test mean result of the experimental class 80,04 greater than the post-test mean of the control class 71,36 . This is evidenced by the t-test obtained $t$ count of 58,45 and t table of 1,71 with a significant level of 5\%. Based on the results of the study, it can be concluded that there is a significant effect of using the flipbook culture story media on the reading literacy of elementary school students.
\end{abstract}

Keywords: Learning Media, Culture Story Flipbook, Reading Literacy

\section{INTRODUCTION}

The progress of a nation can be seen from the level of literacy of its people. The higher the people's interest in obtaining knowledge, the higher the civilization of the nation will be. A person's knowledge can be built through reading activities. Reading is one of the four basic language skills, namely listening, speaking, writing, and reading. Reading has a huge influence on society in facing their future life. The Indonesian nation is a nation with a low literacy level. This is in line with the results of the Progress in International Reading Literacy Study (PIRLS) test, which measures reading literacy in the aspects of understanding, using, and reflecting reading results in written form for fourth-grade elementary school students. Indonesia was ranked 45th out of 48 participating countries with a score of 428 out of an average score of 500 Furthermore, the results of research conducted by the Program for International Student Assessment (PISA) state that the literacy culture of the Indonesian people is the second-worst of the 65 countries studied in the world. Indonesia ranks 64 th out of 65 countries. From the results of this study, none of the Indonesian students achieved literacy scores at level 5; only $0.4 \%$ are at level 4, and the rest are below level 3. This clearly shows that reading interest in Indonesia is still very low compared to other countries.

Based on some of the research and survey results above, it can be seen that the reading interest of the Indonesian people, especially students, is still classified as low. The low reading interest of the Indonesian people is caused by several aspects including 1) The family environment and the surroundings do not support reading habits, 2) The low purchasing power of public books is related to the awareness of the importance of reading books, 3) the lack of an adequate number of libraries, 4) the negative impact of social media, 5) learning media that have not fostered students' reading interest.

Teachers have not made much use of various learning media that can support students' interest in reading. As an important component in learning, the media must be presented to foster students' reading interest as well as to overcome student difficulties related to the process of understanding discourse texts. Reading is still a tedious activity for students in elementary schools because learning to read is often done by repeating the same reading text so that students remember and memorize it without emphasizing that in reading activities students must understand and be able to analyze the content of the text being read. 
Dalman [1] says that reading is an activity or cognitive process that seeks to find various information contained in writing. Samsu Somadayo [2] states that reading is an interactive activity to pick and understand the meaning contained in written material. This opinion is supported by Henry Guntur Tarigan [3] who explains that reading is understanding language patterns from the description of his writing. From some of the opinions above, it can be concluded that reading is a process of associating letters, translating, and understanding the meaning of the reading content.

Listiyanto in Aizid [4] generally describes some of the benefits that readers can get from reading activities as follows: (1) reading can provide several information and knowledge that is very useful in the practice of everyday life, (2) reading can lets you communicate with the thoughts, messages, and impressions of great thinkers from all over the world. Reading can make you communicate with the thoughts, messages, and impressions of great thinkers from all over the world, (3) reading can keep up with the latest developments in science and technology in the world, (4) reading can find out about major events in history, civilization, and culture a nation, (5) reading can solve various life problems and lead you to be smart, clever, and wise in your attitude.

Baleiro [5] states that the definition of literacy must take into account the nature of a concept that examines the existence, contextual, consequences, relative, and culture-related. Literacy is much more than "the capacity of individuals to process written information in everyday life. Furthermore, Suyono [6] states that literacy as the basis for developing effective and productive learning enables skilled students to find and process information that is much needed in 21st-century science-based life.

Reading literacy is a person's ability to understand, use, and reflect on written reading to achieve goals as needed, develop knowledge and potential, and participate in society. Reading literacy is seen from the ability of students to use written texts for socially demanding and useful purposes for individuals to develop their knowledge and potential. In reading literacy, reading is not simple decoding but rather combines understanding and using written information for functional purposes.

Reading literacy according to UNESCO [7] focuses on reading comprehension which includes four main studies, namely: (1) reading skills; (2) application, training, and determination of reading; (3) reading process; and (4) the text used in reading. Furthermore, Geske and Ozola [8] state that the availability of a similar text above can direct students' achievement in reading literacy in a better direction.

Media Flipbook Story culture is a pop up based digital book that incorporates $3 \mathrm{D}$ animation elements containing stories of Indonesian cultural wisdom. This media features stories of Indonesian cultural wisdom with simple language, the storyline is easy to understand by students and contains moral messages as an implementation of character education. This media is also supported by interactive menus, attractive and relevant images, and uses the type, color, and size of letters that are appropriate to the age development of elementary school students.

According to Riyanto et al. [9] flipbooks are a digital book display design that is now in great demand by the public with three-dimensional e-book technology, where pages can be opened like reading a book on a monitor screen. According to Sri Hayati et al. [10] flipbooks can be presented in an electronic format which is capable of displaying interactive simulations by combining text, images, audio, video, animation, and navigation which makes users more interactive with the program so that learning can take place more interesting and fun. Flipbook is one type of classic animation made from a pile of paper that resembles a thick book, on each page, a process depicts something that will appear moving or animated.

The choice of flipbook media was deemed suitable in the development of current learning tools that emphasize modern pedagogical dimensions in learning. This flipbook media complements existing electronic books so that it can accommodate all interactive learning activities such as listening, reading, writing, and also playing games. The flipbook media used can be a combination of text, animation, video, audio, and so on to provide audio and visual stimuli that will improve the memory of students. Audiovisual media have high potential in delivering messages, $70 \%$ more effective, attracting student interest and attention to convey information, entertainment, and education.

\section{METHOD}

The type of research used is quantitative research with experimental methods. The researcher wanted to know the effect of culture story flipbook media on reading literacy of elementary school students in Indonesian language learning. True Experimental Design research design with the type of research used Post Test Only Control Design. Data collection techniques used were observation, interviews, and tests. The normality test used is the Kolmogrov Smirnov method. The homogeneity test uses the Ftest. And the hypothesis testing is done using the t-test formula.

\section{RESULT AND DISCUSSION}

The results of the research on the effect of the culture story flipbook media on reading literacy of elementary school students in Indonesian language learning are as follows: 


\subsection{Data Description of Reading Literacy Post-test Value of Experimental Class Students}

The Experiment Class is a class that uses the culture story flipbook media in Indonesian language learning. Based on the post-test results in the experimental class of $\mathrm{N} 24$ students, the highest score was 95, the lowest score was 65 , the average score was 78.54 .

Table 1. Distribution Of Reading Comprehension Posttest Results In The Experimental Group

\begin{tabular}{ccc}
\hline Interval Score & Frequency & $\begin{array}{c}\text { Percentage } \\
(\boldsymbol{\%})\end{array}$ \\
\hline $65-69$ & 1 & $4.18 \%$ \\
\hline $70-74$ & 5 & $20.83 \%$ \\
\hline $75-79$ & 5 & $20.83 \%$ \\
\hline $80-84$ & 5 & $20.83 \%$ \\
\hline $85-89$ & 6 & $25.00 \%$ \\
\hline $90-95$ & 2 & $8 \%$ \\
\hline Total Score & $\mathbf{2 4}$ & $\mathbf{1 0 0 \%}$ \\
\hline
\end{tabular}

The table above explains the reading literacy results of students in the experimental class using the flipbook culture story media, the lowest score is in the interval 65-69 for 1 student, the highest score is in the 90-95 interval for 2 students, while the highest score is at the interval $85-89$ a total of 6 students.

\subsection{Data Description of Reading Literacy Post-test Score of Control Class Students}

The control class is a class that does not use the culture story flipbook media in Indonesian language learning. Based on the results of the post-test on the control class of N 22 students, the highest score was 85, the lowest score was 60 , the average score was 70.45 .

Table 2. Distribution Of Reading Comprehension Posttest Results In The Control Group

\begin{tabular}{ccc}
\hline Interval Score & Frequency & $\begin{array}{c}\text { Percentage } \\
(\mathbf{\%})\end{array}$ \\
\hline $60-64$ & 5 & $22.72 \%$ \\
\hline $65-69$ & 3 & $13.64 \%$ \\
\hline $70-74$ & 6 & $27.27 \%$ \\
\hline $75-79$ & 3 & $13.64 \%$ \\
\hline $80-85$ & 5 & $22.72 \%$ \\
\hline Total Score & $\mathbf{2 2}$ & $\mathbf{1 0 0 \%}$ \\
\hline
\end{tabular}

The table above explains the reading literacy results of students in the control class using the flipbook culture story media, the lowest score is in the 60-64 interval for 5 students, the highest score is in the $80-85$ interval with 5 students, while the most scores are obtained at the 70 - 74 totaling 6 students

\subsection{Data on the influence of culture story flipbook media on reading literacy of elementary school students}

\subsubsection{Normality test}

This test uses the Kolmogorov-Smirnov design where if the significance value is $<0.05$, the data from the experimental and control groups are normally distributed, on the other hand, if the significance value is $>0.05$, the data from the experimental group and control class are not normally distributed. The following are the results of the Kolmogorov-Smirnov normality test using the SPSS 20 application are as follows:

Table 3. Normality Test

\begin{tabular}{|c|c|c|c|c|}
\hline \multirow{2}{*}{} & \multirow{2}{*}{ Group } & \multicolumn{3}{|c|}{ Kolmogorov-Smirnov } \\
\cline { 3 - 5 } & Statistic & df & Sig. \\
\hline $\begin{array}{l}\text { Reading } \\
\text { Literacy }\end{array}$ & Experiment & 139 & 4 & $200^{*}$ \\
& Control & 129 & 2 & $200^{*}$ \\
\hline
\end{tabular}

From the table above, it is obtained a significance value $>0.05$, so it can be concluded that the population is normally distributed.

\subsubsection{Homogeneity Test}

To find out the variances of several populations, a homogeneity test is needed to determine whether these variances are the same or not. The basis for the decisions taken in the homogeneity test, namely:

- $\mathrm{H}_{0}$ accepted if the significance value is $>0.05$, the variance is homogeneous.

- $\mathrm{H}_{0}$ rejected if the significance value $<0.05$ then the variance is not homogeneous

The following are the results of the SPSS 20 application homogeneity test can be seen in the following table:

Table 4. Test of Homogeneity of Variance

\begin{tabular}{|ll|r|r|r|r|}
\hline & $\begin{array}{r}\text { Levene } \\
\text { Statistic }\end{array}$ & df1 & df2 & Sig. \\
\hline $\begin{array}{l}\text { Reading } \\
\text { Literacy }\end{array}$ & $\begin{array}{l}\text { Based on } \\
\text { Mean } \\
\text { Based on } \\
\text { Median }\end{array}$ &, 142 & 1 & 44 &, 708 \\
&, 136 & 1 & 44 &, 714 \\
\hline
\end{tabular}




\begin{tabular}{|l|l|l|r|r|}
\hline $\begin{array}{l}\text { Based on } \\
\text { Median and } \\
\text { with } \\
\text { adjusted df }\end{array}$ &, 136 & 1 & 42,979 &, 714 \\
$\begin{array}{l}\text { Based on } \\
\text { trimmed } \\
\text { mean }\end{array}$ &, 142 & 1 & 44 &, 708 \\
\hline
\end{tabular}

From the table above, it shows that the initial data for the experimental class and control class have F-count 0.78 and F-table 4.06, then F-count $<$ F-table $(0.78$ $<4.05)$, this shows that the data for the experimental class and control class have homogeneous data.

\subsubsection{T-Test}

To determine the difference in the effect of the culture story flipbook media on reading literacy, data analysis was carried out using the independent sample t-test on the post-test data of the experimental class and the control class. The results of the analysis using the Ttest show that there is a significant difference $\mathrm{T}$-count $>$ T-table at a significant level of $5 \%$

Table 5. One-Sample Test

\begin{tabular}{|c|c|r|r|r|r|c|}
\hline & \multicolumn{6}{|c|}{ Test Value $=0$} \\
\cline { 2 - 7 } & $\mathrm{t}$ & $\mathrm{df}$ & $\begin{array}{c}\text { Sig. (2- } \\
\text { tailed) }\end{array}$ & $\begin{array}{c}\text { Mean } \\
\text { Difference }\end{array}$ & \multicolumn{2}{|c|}{$\begin{array}{c}\text { 95\% Confidence } \\
\text { Interval of the } \\
\text { Difference }\end{array}$} \\
\cline { 5 - 7 } & & & & Lower & Upper \\
\hline Reading & 58,455 & 23 &, 000 & 80,042 & 77,21 & 82,87 \\
\hline
\end{tabular}

Based on the table above, it can be seen that T-count is 58,455 and T-table is 1,71 , then T-count $>\mathrm{T}$-table with a significant level of $5 \%(58,45>1,71)$. Then it can be concluded that there is an influence of the culture story flipbook media on the reading literacy of the experimental class and control class students after being given the treatment.

Based on the results of research that has been carried out, culture story flipbook media affects the reading literacy of elementary school students. This is evidenced by the results of the T-test which shows that T-count is 58,455 while $\mathrm{T}$-table is 1,71 with a significance level of $5 \%$ so that $\mathrm{H}_{0}$ is rejected and $\mathrm{H}_{\mathrm{a}}$ is accepted. So it can be concluded that there is a significant difference in influence between classes that use culture story flipbook media and classes that do not use culture story flipbook media on students' reading literacy. Media Flipbook Story culture in this study is a pop-up book that features stories of Indonesian cultural wisdom with simple language, storylines that are easy to understand by students, and contains moral messages as an implementation of character education. This media is also supported by interactive menus, attractive and relevant images, and uses the type, color, and size of letters that are appropriate to the age development of elementary school students.

Students in learning who use culture story flipbook media are eager to participate in learning than students who do not use culture story flipbook media but they use pictorial text media. Students are more excited and interested in the material presented using the culture story flipbook media because this media is a new medium that they have never known before. Students focus more on the images and text presented in the culture story flipbook media so that it creates more interest in the information presented on each page. The results of this study are supported by research conducted by Dewi Nurul [11] which states that the learning media used influences on reading comprehension literacy because during the learning process students not only listen to explanations from the teacher but students learn in a fun way because students can use learning media that interesting. Beside research conducted by Umar Sulaiman [12] states that learning to read comprehension using Big Book media makes students enthusiastic about participating in it. After waiting for the big book media, the students' literacy skills at Madrasah Ibtidaiyah Negeri Bantaeng Makassar showed that the average score increased tended to be very good.

\section{CONCLUSION}

There is a significant difference in reading literacy between the experimental class who received treatment using the culture story flipbook media and the control class who did not receive this treatment (using picture story media). The difference in reading literacy can be seen by looking at the final results of the t-test between the experimental class and the control class.

The results obtained by T-count is 3,458 and T-table is 1,680 , then $\mathrm{T}$-count $>\mathrm{T}$-Table with a significant level of $5 \%$ (3458> 1680). So it can be concluded that there is an influence of the culture story flipbook media on the reading literacy of the experimental class and control class students after being given the treatment.

\section{ACKNOWLEDGMENT}

Authors would like to say thank you for all who already had supported us during research process. 


\section{REFERENCES}

[1] Dalman. Ketrampilan Membaca. Jakarta: Kharisma Putra Utama Offset. 2013

[2] Samsu Somadayo. Strategi dan Teknik Pembelajaran Membaca, Yogyakarta : Graha Ilmu. 2011.

[3] Henry Guntur Tarigan. Membaca Sebagai Suatu Keterampilan Berbahasa. Bandung: Penerbit Angkasa. 2012.

[4] Aizid, Rizem. Bisa Baca Secepat Kilat (Super Quick Reading). Jogjakarta : Bukubiru. 2011.

[5] Baleiro, R. A Definition of Literary Literacy: A Content Analysis of Literature Syllabuses and Interviews with Portuguese Lecturers of Literature. Journal of New Horizons in Education, (1). 2011. http://www.tojned.net/ pdf/tojnedv01i04-02.pdf.

[6] Suyono \& Hariyanto. Belajar Dan Pembelajaran (Teori Dan Konsep Dasar). Bandung: Rosdakarya. 2014.

[7] UNESCO. Literacy for Life. Paris (Prancis): United Nations Educational, Scientific, and Cultural Organization. 2005.

[8] Geske, A.\& Ozola, A. Factors Influencing Reading Literacy at The Primary School Level. Journal Problems of Education in The 21st Century, (6) $\quad 1.2018$. http://www.jbse.webinfo.lt/71-77.Geske.pdf.

[9] Riyanto, Lukman \& Subagyo. Pengembangan Digital Library Local Content Pekalongan Dalam Format Buku 3 Dimensi. Jurnal LIPI 1(1):1-13. 2012.

[10] Sri Hayati, Agus Setyo Budi, Erfan Handoko. Pengembangan Media Pembelajaran Flipbook Fisika Untuk Meningkatkan Hasil Belajar Peserta Didik. (Prosiding Seminar Nasional Fisika EJournal SNF Vol.IV) . 2015

[11] Fatimah, Dewi Nurul. Pengaruh Media Kartu Kalimat Terhadap Literasi Membaca Pemahaman Di Kelas Rendah. Jurnal Perseda. Vol 2. No 3. 2019.

https://jurnal.ummi.ac.id/index.php/perseda/article/ view/446/454

[12] Umar Sulaiman. Pengaruh Penggunaan Media Big Book Dalam Pembelajaran Terhadap Keterampilan Literasi Siswa Kelas Awal Madrasah Ibtidaiyah Negeri Banta-Bantaeng
Makassar. Jurnal al-Kalam. Vol. IX No. 2. 2017. http://journal.uin-

alauddin.ac.id/index.php/klm/article/viewFile/4486 $\underline{14103}$ 